\title{
Plus ça change, plus c'est la même chose
}

\begin{abstract}
In a letter to Robert Hooke, Isaac Newton wrote, "if I have seen farther than others, it is by standing on the shoulders of giants." While I claim neither the intellectual ability of Sir Isaac Newton, nor superior distance vision to others, as editor in chief of the JCI for the last five years, I clearly have stood on the shoulders of giants - and have benefitted greatly from it.
\end{abstract}

So, in thinking about what my parting words would be, I decided to read my immediate predecessor's last editorial. Among other things, Andy Marks remarked how wars and natural disasters have overwhelmed the US economy and compromised funding for biomedical research, and reminded us that translational research is the "buzzword," but we can't agree what it is or how to go about it (1).

The more things change, the more they remain the same.

I am tempted to opine yet further on the sorry state of biomedical funding, but I am too busy trying to write my competing renewals (yet again!). However, in all seriousness, I can think of no greater threat to biomedical research. The fear in the room among scientists at all levels, even very senior ones, is palpable. I have not seen anything quite like it in my career, and it is profoundly worrying. My guess is that this is not just a transient period of hard times but the beginnings of a major shift in how we think about and perform research.

As Niels Bohr wrote, "predictions are hard to make, especially about the future," but my prediction is that big science is here to stay, and we will see a decrease in the number of, and emphasis on, independent individual scientific investigators. Much as happened with the physical sciences, we will see increasing use of directed funding, fueling large team formation to solve big problems in biomedical research. This will involve partnerships among academia, industry, government, and the private sector. For individual scientists, the drivers will be the ability to address important issues beyond the scope of an individual lab and, quite frankly, career survival, as we all depend upon grants and contracts, and this is where increasing amounts of the monies will be going. Success will require new models for these types of partnerships and a major shift in how our universities define success for faculty, as promotions committees will have to de-emphasize independence and devise metrics to measure team achievement. And to some extent, I believe this is a good thing, as both artificial divisions between academia and industry and the reluctance of many to join teams and forego individual recognition threaten progress. We know more now about health and disease than most of us could have imagined only 20 years ago - it is time to accelerate the translation of that knowledge into better prevention and treatments.

The JCI has an important role in that process, and the editorial board took that mandate to heart. In response to complaints about the "mouse-focused" nature of the JCI, we made a concerted effort to be more "human-study friendly." As I wrote in an editorial, "Animal house" (and I received more correspondence about this than anything else I have ever written), fully one-third of the work we published in our first year dealt with human investigation or human samples (2). I am confident the number is even higher now. And clearly the research community is interested is this -11 out of the top 20 papers (from our term of office) downloaded from the $J C I$ website involved studies on human subjects or human samples. Perhaps not surprisingly, the top three of those dealt with marijuana (3), soda consumption (4), and male-pattern baldness (5)!

To find the best papers to publish, we leaned heavily upon our expert reviewers. The increasing pressures of academic life made me worry that it would be difficult to obtain high-quality reviews in a timely manner. Although we have perhaps seen a bit more of the "I apologize for being late but I have 6 grant applications due next week, I'll get this in as soon as I can" type of e-mails, the overwhelming majority of our reviewers are on time (or nearly so!), with impartial and insightful comments. For this the board and I are profoundly grateful.

As might be expected, impartiality is somewhat less evident in authors. We have had approximately 20,000 manuscripts submitted to us in the past five years, a sizable number on which to reach conclusions. Somewhere around $10 \%$ of our decisions to reject a paper elicit a vigor- ous protest, a number that truly surprised me. Among some of the more memorable responses: "Obviously a misunderstanding had led to the decision that the revised manuscript did not achieve the priority necessary for publication," or "The phrase 'lack of mechanism' as a justification for rejection is really getting me upset lately (this is not the first time). If I provided to you ironclad proof of a singing dog, would you reject the manuscript because I don't know how he does it?," or my personal favorite "You published a worse paper on the same topic!"

Despite the assaults on our morals, character, and intelligence, we have worked hard to retain our equanimity, often bolstered by the sense of our reviewers and editors. Who could avoid laughing at the following: "The paper is well illustrated and has enough data for persuasion but not enough for stupor, for which the authors are to be applauded," or "To become appropriate for publication this work would require... an almost miraculous improvement of the conceptual rigor," or "Here is the problem that I have with this paper: I don't believe a word of it," or "Maybe this is all there is but I do believe that this is why the Creator created Immunology journals. This is not what I want to read in JCI," or "Here is what I was able to understand: if you feed guinea pigs nasty chemicals they will become sick, and their myeloid cells will produce new bands on protein gels. The moral: don't try this at home with your pets." And one that I will never forget: "I really hope this manuscript is not published somewhere with these data. How does one prevent this from happening?"

Many talented people have worked hard to make the JCI successful. We simply could not function without our full-time professional editors, Brooke Grindlinger (now at the New York Academy of Sciences), Karen Honey, Kathryn Claiborn, and Ushma Neill. They have done a tremendous amount of work, often behind the scenes, which was essential for the smooth operation of the journal. Ushma, our executive editor, deserves to be singled out in particular - her professionalism, standards of excellence, and sense of fairness are admirable. We also could not have produced the journal without the publishing staff in Ann Arbor, Michigan, led by John Hawley 
and Karen Guth. I am similarly immensely thankful for their team's efforts.

And, of course, what success I may have enjoyed as editor in chief was completely dependent on the members of the editorial board at Penn. The average associate editor saw as many as 1,000 manuscripts in his/ her in-box during the past five years - no mean feat - and handled them all without (too much) complaining. More importantly, the camaraderie and humor (yes, journal editing can be funny) at our weekly editorial board meetings made it all worthwhile. I had the opportunity to work with many colleagues that I had not known well and formed new friendships that will last long beyond my tenure as editor. I particularly want to thank the deputy editors, Morrie Birnbaum, Jon Epstein, and Gary Koretzky, and a former deputy editor, Steve Emerson. They worked hard and were the source of sound advice, and I simply could not have done this job without them.

The editorial board itself underwent significant change over the past five years. Out of the 19 associate editors on the board, only 8 were founding members from 2007. This change was both desired and good new editors helped reenergize us with their enthusiasm and also brought new scientific ideas and perspectives. While most rotations on and off the board were planned, two were not. Tragically, two board members passed away during the past five years,
Rich Spielman and Alan Gewirtz. We continue to mourn their loss.

On the theme that turnover is good, a new sheriff, Howard Rockman, is in town. I don't know exactly what the JCI will look like in the next few years, but I do know that Howard Rockman, and his team at Duke and UNC, are a terrific choice to lead the journal. I know many of the incoming editors personally, I am certain they will do a fine job in making the JCI an even better journal than the one they are about to inherit. I have been particularly impressed with Howard's enthusiasm and new ideas, and changing of the guard is the best way to periodically reinvigorate the JCI. My advice to them is to have fun; the time goes by remarkably quickly. And have a thick skin - you will make a lot of people mad at you, but have confidence in yourselves and you won't fail.

As some of you may know, I moved to Boston midway through my term as editor. I thank my Penn colleagues for allowing me to continue via frequent travel to Philadelphia and video conferencing. I appreciate as well the support and indulgence of Mark Zeidel and the leadership at Beth Israel Deaconess Medical Center for allowing me to take the time to complete my term.

I have been asked many times in the last few months "will you miss being the JCI editor"? The answer vacillates between a resounding yes! and no! Top reasons to miss being editor: the fun of our editorial board meetings, the privilege of seeing the immense amount of good science that is submitted to the JCI, and the pride in helping bring the best science to our readers. Reason not to miss being editor: it takes a lot of time. Like all outgoing editors, I also am often asked what I will do with all my newfound free time. High on the list are spending time in my lab, reading books, watching movies, and going to baseball games. And I suppose I will be spending more time waiting - I am resigned to the fact that my phone calls are not going to be returned so quickly anymore (my five years of pseudo-importance is about to end, sigh!).

\section{Laurence A. Turka, Editor in Chief}

1. Marks AR. Hello, goodbye. J Clin Invest. 2007; 117(2):280-281.

2. Turka LA. Animal house. J Clin Invest. 2008; 118(3):822-822.

3. Salazar M, et al. Cannabinoid action induces autophagy-mediated cell death through stimulation of ER stress in human glioma cells J Clin Invest. 2009;119(5):1359-1372.

4. Stanhope KL, et al. Consuming fructose-sweetened, not glucose-sweetened, beverages increases visceral adiposity and lipids and decreases insulin sensitivity in overweight/obese humans. J Clin Invest. 2009;119(5):1322-1334.

5. Garza LA, et al. Bald scalp in men with androgenetic alopecia retains hair follicle stem cells but lacks CD200-rich and CD34-positive hair follicle progenitor cells. J Clin Invest. 2011;121(2):613-622. 